\title{
COMMUNITY SERVICE PROGRAMS IN HIGH SCHOOLS
}

\author{
SALLY A. RASKOFF* AND RICHARD A. SUNDEEN** \\ TABLE OF CONTENTS
}

I. Introduction.

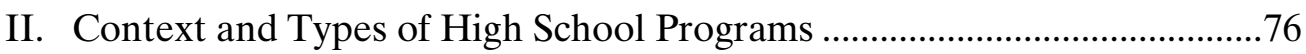

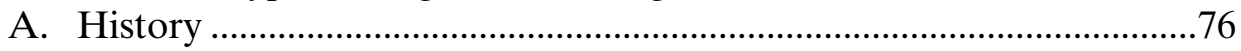

B. Purposes/Rationales of Community Service ........................................78

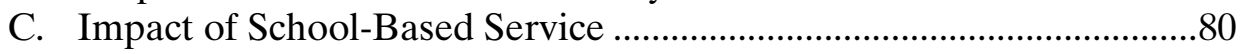

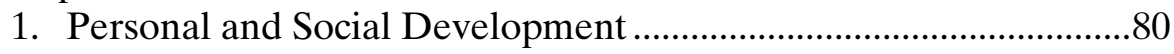

2. Academic and Cognitive Development .........................................81

3. Political Efficacy and Civic Engagement .........................................81

4. Limitations of Research on Community Service ...........................82

D. Program Elements and Processes .......................................................82

1. Program Structure and Components ................................................83

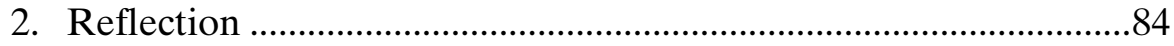

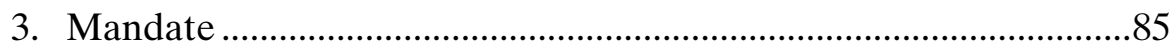

4. Collaboration between School and Community

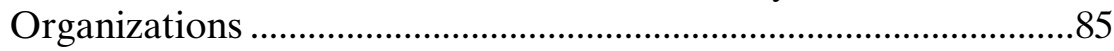

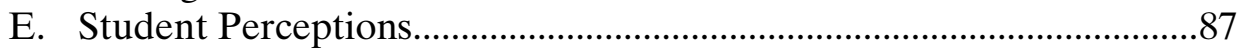

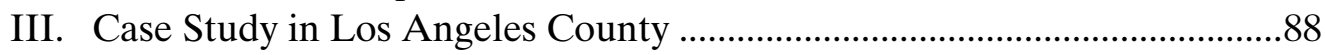

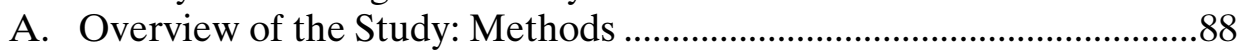

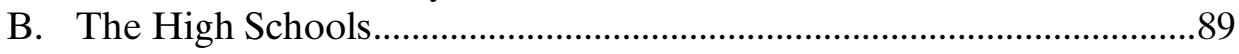

1. Prevalence of Community Service Programs ..................................89

2. Program Elements ...........................................................................89

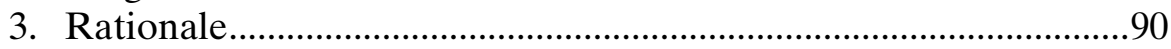

C. Relationships between Schools and Community Organizations ........90

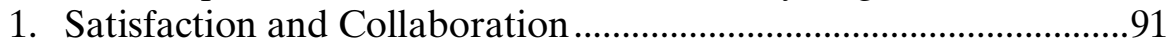

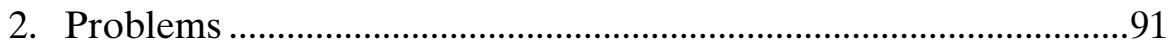

3. Conclusion and Summary .............................................................92

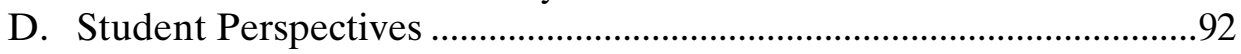

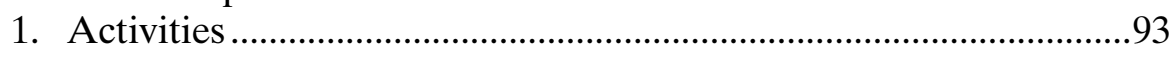

2. Encouragement to Participate........................................................94

Copyright $@ 2000$ by Sally A. Raskoff and Richard A. Sundeen

This article is also available at http://www.law.duke.edu/journals/62LCPRaskoff

The research for this article was made possible by grants from the Aspen Institute and the John Randolph and Dora Hayes Foundation.

* Lecturer in Sociology, University of Southern California.

** Professor and Associate Dean, School of Policy, Planning, and Development, University of Southern California. 
3. Encouragement of the Connection between Service and

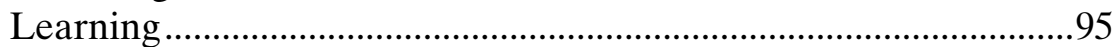

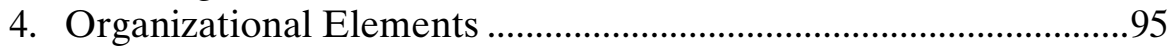

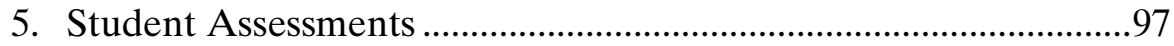

a. Positive experiences.....................................................................99

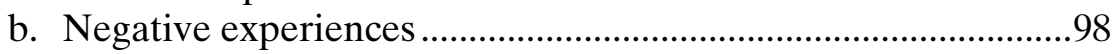

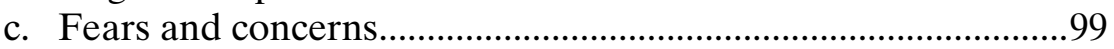

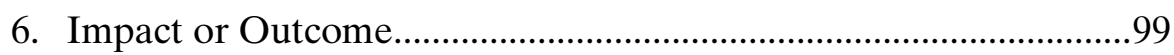

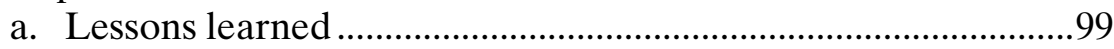

b. Future intentions to participate..............................................100

7. Summary of Student Perspectives ..................................................100

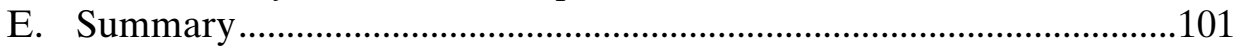

IV. Conclusions and Recommendations.......................................................101

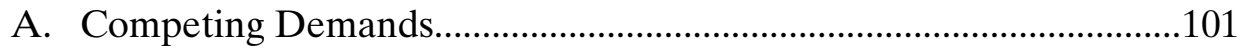

B. Clarity of Program Elements ...............................................................103

1. Communication and Collaboration with Community Organizations ...........................................................................103

2. Important Resources: Time and Money ......................................104

C. The Need for Organization ..............................................................104

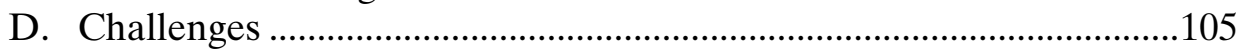

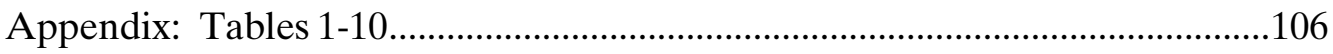

\section{I}

\section{INTRODUCTION}

Numerous observers have commented on the need to increase civic participation, including volunteering, as a means of strengthening our democratic system. ${ }^{1}$ In the United States, with its strong tradition of volunteerism in the provision of services, the creation of social capital, and the representation of collective interests, the inclusion of young persons in volunteer roles is extremely important. ${ }^{2}$ Consequently, the socialization of youth into community service roles has become a topic of considerable interest in the United States, and educational policymakers, educators, and the media have begun to focus their attention on the role of community service in school settings. This article examines youth socialization and civic participation through community service among high school students, with special focus on southern California.

1. See, e.g., Robert Bellah, Habits of THE HeART: INDIVIDUAlism AND COMMITMENT IN AMERICAN LIFE (1985); Robert PUTNAM, MAKING DEMOCRACY WORK: CIVIC TRAdITIONS IN MODERN ITALY (1993); Brian O'Connell, A Major Transfer of Government Responsibility of Voluntary Organizations? Proceed with Caution, 56 PUB. ADMIN. REv. 222-25 (1996); Robert Putnam, Bowling Alone: America's Declining Social Capital., 6 J. DEMOCRACY 65 (1995).

2. For discussions of youth volunteering and service in the United Kingdom, see Katherine Gaskin, Vanishing Volunteers: Are Young People Losing Interest in Volunteering?, 1VOLUNTARY ACTION 33 (1998); Debra Roker, School-based Community Service: A British Perspective, 17 J. ADOLESCENCE 321 (1994). 
Along with the contributions that volunteerism makes to society, the younger volunteers also purportedly benefit from increased self-esteem, academic skills, career and occupational direction, community involvement, and political skills. ${ }^{3}$ The resulting effective socialization of its younger members will ensure that society has a sufficient supply of competent "amateur" policy implementers and active citizens. Without effective socialization, in the cautionary words of a recent observer, "we are in danger of producing a whole generation of children with [civic] and philanthropic retardation."

The agents of socialization through and from whom young persons usually learn about the values and behavior appropriate for volunteer roles include families, churches, schools, other community associations and organizations, peer groups, and the media. Earlier research, for example, found that adults whose parents volunteered or who volunteered with their family when they were young are more likely to volunteer than adults whose parents did not volunteer or who did not volunteer with family. ${ }^{5}$ Also, in a national survey of teenagers, Sundeen and Raskoff found that, while schools, families, and churches all played important roles in shaping volunteer behavior by the respondents, the strongest predictive variable was attending a school that encouraged or required community service. ${ }^{6}$ In addition, a recent study on political participation has underscored the importance of high school activities in contributing to adult participation. ${ }^{7}$

Most schools provide their students with at least the opportunity to participate in service activities, and many now require participation or give class credit for it. For example, in 1995, nearly fifteen percent of the 130 largest school districts had a district-wide service requirement for graduation, and forty-five percent had at least one school that required volunteer service. ${ }^{8}$ In 1998 , nearly twenty percent of the fifty largest school districts required volunteer service, and nearly one-half provided the opportunity to earn academic credit for community service participation. $^{9}$

3. See Lillian Stephens, The COMPlete Guide to LeARning through Community SERVICE: GRADES K-9 (1995); R. WADE, COMMUNITY SERVICE LEARNING: A GuIDE TO INCLUDING SERVICE IN THE PUBliC SCHOOl CURRICUluM (1997); Vito Perrone, Learning for Life: When Do We Begin?, 26 EQUITY \& EXCELLENCE ED. 5 (1993).

4. See Deborah Spaide, Charities Must Give Kids the Chance to Serve Others, CHRON. PHILANTHROPY, Feb. 11, 1999, at 36.

5. See generally Virginia A. Hodgkinson et al., Giving and Volunteering in the United States, 1994, in 2 TRENDS IN GIVING AND VOLUNTEERING BY TYPE OF CHARITY 241 (Hodgkinson et al. eds., 1995).

6. See generally Richard Sundeen \& Sally Raskoff, Volunteering among Teenagers in the United States, 23 NONPROFIT \& VOLUNTARY SECTOR Q. 383 (1994); Richard Sundeen \& Sally Raskoff, Teenage Volunteers and their Values, 24 NONPROFIT \& VOLUNTARY SECTOR Q. 337 (1995); Richard Sundeen \& Sally Raskoff, Teenage Volunteers: Findings and Implications for Public Policy, in PROCEEDINGS OF THE 1995 SPRING RESEARCH FORUM (1995).

7. See generally SYDNEY VERBA ET AL., VOICE AND EQuAlity: CiVIC VOluntarism IN AMERICAN POLITICS (1995).

8. See National and Community Service Coalition, Youth Volunteerism: Here's What the Surveys Say, Service Brief, Washington, D.C., Dec. 15, 1995.

9. See Marina Dundjerski \& Susan Gray, A Lesson in Mandatory Service, 22 CHRON. PHILANTHROPY 1, 29-32 (1998). 
This article focuses on high school community service programs: their practices, their collaborative relations with community organizations for which the students volunteer, and the perspectives of students regarding their participation in these school-sponsored programs.

II

\section{CONTEXT AND TyPES OF High SCHOOL PROGRAMS}

\section{A. History}

The current support for school-based volunteer service in the United States has developed along two lines that have occasionally intersected. One source of support has come from those interested in the educational and characterbuilding benefits of service for students. The other source of support has come from governments, especially the federal government, but also some state governments.

Support for educational programs can be traced to at least the early 1900s. In 1907, arguing for civic education in public schools, Arthur Dunn extolled the virtues of community participation that rested upon "the feeling of personal responsibility for community affairs."10 The work of John Dewey, including his call in 1910 for the "moral equivalent of war" that would be possible through service $^{11}$ and his assumption that "learning must be grounded in experience,", has also been significant in the development of various kinds of applied and experiential learning. While the Progressive Movement continued through the 1920 s and 1930s to promote experiential and service-based learning, it was not until the 1970s that there was a significant increase in interest in communityservice learning activities among educators and other observers. Numerous reports, emanating from national foundations, commissions, universities, and the federal government, decried the alienation of American youth and called for reforms of public education, including community-service learning, work-study programs, internships, and community participation. ${ }^{13}$ The late $1980 \mathrm{~s}$ and $1990 \mathrm{~s}$ have seen another upsurge of interest by educators, policymakers, researchers, and students in volunteerism, community service, and service learning. At the university level, Campus Compact (and its various state affiliates) and Campus Opportunity Outreach League ("COOL") exemplify the importance given to student service by university administrators and students. These two organiza-

10. Mary A. Hepburn, Service Learning in Civic Education: A Concept with Long, Sturdy Roots, 36 THEORY INTO PRACTICE 135, 136 (1997).

11. Richard J. Kraft, Service Learning: An Introduction to Its Theory, Practice, and Effects, 28 ED. \& Urban SoC'Y 131, 135-36 (1996); Miranda Yates \& James Youniss, Community Service and PoliticalMoral Identity in Adolescents, 6 J. RES. ADOLESCENTS 271, 272 (1996).

12. See Susan C. Root, School-Based Service: A Review of Research for Teacher Educators, in LEARNING WITH THE COMMUNITY: CONCEPTS AND MODELS FOR SERVICE-LEARNING IN TEACHER EDUCATION 42, 43 (Joseph A. Erickson \& Jeffrey B. Anderson eds., 1997).

13. See Marc Leepson, National Service, CONG. Q. RES., June 25, 1993, at 555, 562; Hepburn, supra note 10, at 138; Kraft, supra note 11, at 134; Root, supra note 12, at 441. 
tions, both founded in the 1980s, are dedicated to encouraging participation in service activities among university and college students. ${ }^{14}$ At the secondary and elementary levels, many school districts require community service experiences for graduation, and most at least encourage service activities by their students. ${ }^{15}$

Besides the encouragement of service through schools, others have supported government-sponsored national service initiatives, including the Plattsburg Movement from 1915 to 1917 to provide voluntary military training and "moral awakening" to young males; the Civilian Conservation Corps, in the 1930s, and the Youth Conservation Corps and Young Adult Conservation Corps, in the 1970s, to assist unemployed young persons in finding meaningful employment through conservation work in rural areas; and the Peace Corps and its domestic counterpart, Volunteers in Service to America ("VISTA"), founded in the 1960s, to encourage citizens to work in low-income communities as community organizers and service providers. ${ }^{16}$ However, not all of these programs were designed specifically for young persons, and the participants might have received remuneration.

In the late 1980s and 1990s, beginning with the Bush Administration and continuing with the Clinton Administration, the federal government sponsored several initiatives aimed at increasing volunteer participation in communities and schools. For example, the 1990 National Community Service Act authorized the Commission on National and Community Service, "which funded seven pilot programs for local community service." 17 In 1993, the National and Community Service Trust Act authorized the Corporation for National Service, which has funded Learn and Serve America, VISTA, various youth conservation corps, Americorps, and several state-level programs devoted to servicelearning for schools. ${ }^{18}$ For example, Learn and Serve America "seeks to promote youth as resources through service-learning that address local priorities in the areas of education, public safety, the environment, health and human needs." 19

Besides government programs at the federal level, several states sponsor programs that either mandate or encourage community service in public schools. For example, Maryland now requires that all public school districts include service in their curriculum or require students to carry out seventy-five hours of service before they graduate from high school. ${ }^{20}$ In 1991, California created the CalServe Initiative, through which the Department of Education

14. For a history of the service-learning movement in higher education, see TIMOTHY K. STANTON

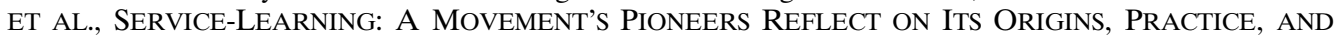
FUTURE (1999).

15. See Dundjerski \& Gray, supra note 9, at 29-30.

16. See Leepson, supra note 13, at 563-65.

17. Id. at 567 .

18. See Yates and Youniss, supra note 11, at 273; Hepburn, supra note 10, at 140-41.

19. See California Department of Education, Family and Community Partnerships, Executive Summary: An Evaluation of K-12 Service Learning in California: Phase II Final Report (Mar. 6, 2000) $<$ www.cde.ca.gov/cfsbranch/lsp/rppexec.htm >.

20. See Suzanne Goldsmith, The Community is Their Textbook, 22 AM. PROSPECT 51, 51-57 (1995). 
"provides direct funding assistance to [thirty-six] school-community partnerships." ${ }^{21}$ CalServe has set as its goal that half of the state's school districts will have service learning as part of their curricula for all grade levels by 2004 .

In addition to government initiatives to promote youth service, various nonprofit organizations with interests in youth service have emerged, including Youth Service America and the Constitutional Rights Foundation at the national level. Youth Service California, "[which] acts as convener, networker, and promoter to build statewide movements where young people are seen as powerful resources in meeting community needs," exemplifies these organizations at the state level. ${ }^{22}$

\section{B. Purposes/Rationales of Community Service}

As suggested by the brief historical review, several rationales and/or purposes have developed for community service among high school students. Studies of community service define the term differently, ${ }^{23}$ and several approaches or models of community service exist. For example, Andrew Furco has developed a typology of community service programs based on "two structural dimensions: (1) the degree to which service is integrated with the school curriculum ... [and] (2) the institution [for example, school or agency] where the program is based." ${ }^{24}$ Furco's typology of service program goals provides a useful summary of rationales and their relationship to student needs, the nature of the local community, and the type of school. ${ }^{25}$ Depending upon these factors, a school may incorporate any or all of five service program philosophies to further its educational aims: social development, personal and moral development, vocational development, academic achievement, and political development.

Several writers have developed conceptual typologies that attempt to distinguish between the focus on the young person and the focus on education. For example, Conrad and Hedin summarized the approaches to community service as "the reform of youth" or "the reform of education." 26 Specific approaches in the reform of youth include those that focus on the development of personal

21. See Youth Service California, Charting the Course for Service-Learning in California: Recommendations from the Field (Mar. 6, 2000) <www.ysca.org/pubs.html>.

22. Id. at 10 .

23. Regarding distinctions between various service programs, including volunteerism, community service, community-based learning, peer-helping, internships, field education, and service learning, see Eleanor Brown, The Scope of Volunteer Activity and Public Service, 62 LAW AND CONTEMP. PROBS. 17 (Autumn 1999); Andrew Furco, Service-Learning: A Balanced Approach to Experiential Learning, in EXPANDING BOUNDARIES: SERVICE AND LEARNING 1, 3-5 (Jody Raybuck ed., 1996); Kraft, supra note 11 , at 133 .

24. Regarding other forms of school-based service learning and community-based programs, see Andrew Furco, A Conceptual Framework for the Institutionalization of Youth Service Programs in Primary and Secondary Education, 17 J. ADOLESCENCE 395, $401-05$ (1994); see also Robert Shumer \& Brad Belbas, What We Know about Service Learning, 28 ED. \& URBAN SOC'Y 201 (1996).

25. See Furco, supra note 24, at 401.

26. Dan Conrad \& Diane Hedin, School-based Community Service: What We Know From Research and Theory, 72 PHI DELTA KAPPAN 743-49 (1991). 
growth and self-esteem ${ }^{27}$ political and moral identity $;^{28}$ social development, responsibility, and obligation ${ }^{29}$ developmental needs of at risk adolescents $;{ }^{30}$ career and job skills education; ${ }^{31}$ and leadership training. ${ }^{32}$ Others emphasize educational and learning rationales of community service. ${ }^{33}$ For example, Kate McPherson and Mary Nebgen discuss the need to connect curriculum and quality of life through community service that meets diverse learning styles. They focus on "life-relevant learning," which includes student involvement in "authentic work," higher-order cognitive skills, and partnerships between schools and communities. ${ }^{34}$

Another general category of rationales for school-based service is the development of citizenship or civic participation. ${ }^{35}$ For example, Richard Battistoni argues that "service learning should be valued as a method of developing in students an other-regarding ethic appropriate to democratic citizenship.",36 Within this general ethical framework, he makes the distinction between a philanthropic service emphasis rooted in altruism and a "civic view" based on enlightened self-interest that "emphasizes mutual responsibility and the interdependence of rights and responsibility." ${ }^{37}$ The "civic view" focuses on learning about diversity, developing "intellectual understanding," acquiring communication skills, and positive attitudes, taking "civic action," and promoting a democratic classroom. ${ }^{38}$

27. See Diane C. Calleson et al., Service-Learning in One State: Results of the North Carolina ServiceLearning Inventory, 22 NAT'L. SOC. EXPERIENTIAL EDUC. Q. $8-9$ (1996); Shumer \& Belbas, supra note 24, at 215; Root, supra note 12, at 50.

28. See Miranda Yates \& James Youniss, A Developmental Perspective on Community Service in Adolescence, 5 SOC. DEV. 90-91 (1996); Root, supra note 12, at 47-50.

29. See generally Charles Harrison, Student Service: The New CARnegie Unit (1987); Calleson, supra note 27; Root, supra note 12.

30. See Joan Schine, School-based Service: Reconnecting Schools, Communities, and Youth at the Margin, 36 THEORY INTO PRACTICE 170-75 (1997).

31. See Anne Lewis, Urban Youth in Community Service: Becoming Part of the Solution, 8 ERIC/CUE DiG. 1, 1-4 (1992).

32. See Calleson, supra note 27 , at 9.

33. See generally Roland MacNichol, Service Learning: A Challenge To Do the Right Thing, 26 EQUITY \& EXCELLENCE IN EDUC. 9-11 (1993); Perrone, supra note 3; Root, supra note 12.

34. See Kate McPherson \& Mary K. Nebger, Community Service and School Reform Recommendations, 23 EDUC. \& URB. SOC'Y 327-28, 333 (1991).

35. See Richard M. Battistoni, Service Learning and Democratic Citizenship, 36 THEORY INTO PRACTICE 150-56 (1997); Harry Boyte, Community Service and Civic Education, 72 PHI DeLTA KAPPAN 765-67 (1991); Todd Clark et al., Service Learning as Civic Participation, 36 THEORY INTO PRACTICE 16569 (1997); S.F. Hamilton \& R.S. Zeldin, Commentary: Learning Civics in Community, 17 CURRICULUM INQUIRY 407-20 (1987); Novella A. Keith, School-based Community Services: Answers and Some Questions, 17 J. ADOLESCENCE 311-20 (1994); Sandra J. Le Sourd, Community Service in a Multicultural Nation, 36 THEORY INTO PRACTICE 157-63 (1997); MacNichol, supra note 33; Perrone, supra note 33; Root, supra note 12; Robert A. Rutter \& Fred M. Newman, The Potential of Community Service to Enhance Civic Responsibility, 53 Soc. EDUC. 371-74 (1989); Mary B. Stanley, Service Learning as Civic Education: Difference, Culture War, and the Material Basis of a Good Life, in EdUCATING TOMORROW's VALUABLE CITIZEN 151-77 (Joan N. Burstyn ed., 1996).

36. Battistoni, supra note 35, at 150.

37. Id. at 151 .

38. Id. at 151-54. 
Some writers prefer to distinguish between civic duty and social action. For example, Joseph Kahne and Joel Westheimer point out that kindergarten through twelfth grade ("K-12") service learning programs can be categorized into those that promote charity and a sense of altruism and those that promote change and methods of social reform. ${ }^{39}$ Whether a program is based on the values of charity or change has significant implications for the implementation of the moral, political, and intellectual goals of a program. For example, a program based on a charity rationale would focus on giving, civic duty, and the educational experience, while a change-oriented program would emphasize caring, social reconstruction, and a transformative educational experience that combines learning with action. ${ }^{40}$ Novella Keith also describes two traditional rationales for service: (1) as a means to "character building, the integration of youth into society, and the promotion of civic responsibility" or (2) as a means to contribute to "the active involvement of students in a learning process [that integrates] academic and developmental task." ${ }^{41}$ However, he argues that service may "play a more central role ... in educational and social reforms" through promoting "participation, tolerance, and social responsibility ... . while also acting as a partial substitute for the declining role of government in social programs."

There are three general areas of program rationales that highlight different benefits of the community service experience. The first, which centers on personal, social, and career development, focuses on the individual; the second, which centers on academic skills, focuses on the school; and the third, which is based on civic engagement, emphasizes the societal aspects of service. If taken seriously by program administrators, each rationale plays an important role in shaping and guiding the development and implementation of a community service program. This, in turn, can affect the students' experiences and the impact of a program.

\section{Impact of School-Based Service}

Research on the impact of school-based service on students in terms of program rationales or goals has increased in the past five years. Several reviewers of this literature have concluded that the findings, at best, are "mixed."

1. Personal and Social Development. Considerable agreement exists among the reviewers that community service participation is positively

39. See Joseph Kahne \& Joel Westheimer, In the Service of What? The Politics of Service Learning, 77 PHI DELTA KAPPAN 594 (1996).

40. See id. at 595.

41. Keith, supra note 35, at 312.

42. Id. at 313 .

43. For reviews of the literature, see JAMES Youniss \& MiRANDA YATES, COMMUNITY SERVICE AND SOCIAL RESPONSIBILITY (1997); Conrad \& Hedin, supra note 26; Kraft, supra note 11; Root, supra note 12; Shumer \& Belbas, supra note 24; Rahima C. Wade \& David W. Saxe, Community ServiceLearning in the Social Studies: Historical Roots, Empirical Evidence, Critical Issues, 24 THEORY \& RES. SOC. EDUC. 331-59. 
associated with students' personal and social development. For example, for students who volunteer, they have reported increased levels of personal and social responsibility, self-esteem, moral development, ${ }^{44}$ identity development, ${ }^{45}$ and career awareness. ${ }^{46}$

However, some studies have not yielded positive findings, and "even the best programs are likely to result in only modest (albeit valuable) gains." ${ }^{47}$ Furco reported mixed results on the impact of service programs on vocational development. ${ }^{48}$ Also, while Richard Kraft agrees that these programs may improve participants' self-esteem, he calls the findings on social outcomes "mixed." Factors, such as "small sample size, lack of strict controls, the effect of previous volunteer experiences on the part of students, and the uneven quality of students' experiences in the program," ${ }^{50}$ make these studies less credible.

2. Academic and Cognitive Development. In the area of academic, intellectual, or cognitive development, the reviewers found that participation in service learning was associated with skills development, ${ }^{51}$ increased knowledge of subject matter ${ }^{52}$ higher-order thinking, ${ }^{53}$ and improved attendance and grade point averages. ${ }^{54}$ On the other hand, Rahima Wade and David Saxe concluded that "research evidence for the impact of service-learning on academic development is neither extensive nor conclusive." ${ }^{55}$ Kraft also asserted that "the findings on intellectual learning and participation in experiential and servicelearning programs are mixed." ${ }^{, 56}$ While there is evidence that tutoring leads to increased cognitive outcomes, "other forms of experiential and service learning ... tested for gains in factual knowledge... have been less conclusive [as possibly caused by] researcher bias and lack of test validity." 57

3. Political Efficacy and Civic Engagement. A positive relationship between participation in school service activities and various forms of civic engagement and political efficacy has the least support from research. Findings regarding the impact of service on political efficacy, ${ }^{58}$ civic development, ${ }^{59}$ and

44. See Conrad \& Hedin, supra note 26, at 747; Kraft, supra note 11, at 148-49; Shumer \& Belbas, supra note 24, at 217.

45. See Root, supra note 12, at 50; Yates \& Youniss, supra note 11, at 275.

46. See Shumer \& Belbas, supra note 24, at 217.

47. See Wade \& Saxe, supra note 42, at 346.

48. Furco, supra note 24, at 400.

49. Kraft, supra note 11, at 146-48.

50. Id. at 146 .

51. See Conrad \& Hedin, supra note 26, at 746.

52. See id. at 746; Root, supra note 11, at 47.

53. See Conrad \& Hedin, supra note 26, at 746; Root, supra note 11, at 46.

54. See Shumer \& Belbas, supra note 24, at 216-17.

55. Wade \& Saxe, supra note 42 , at 341.

56. Kraft, supra note 11, at 151.

57. Id. at 151 .

58. See Conrad \& Hedin, supra note 26, at 747; Root, supra note 11, at 48. 
plans for future participation in community service ${ }^{60}$ appear to be mixed or negative. On the other hand, Miranda Yates and James Youniss proposed that community service increases one's capacity to think about "society's political organization and moral order, and one's agency in relation to these domains." Wade's and Saxe's explanation of this weak relationship between service and political involvement is that "when programs promote an individualistic, charitable conception of service and do not tie their activities to political issues or organizations, participants are unlikely to gain on this dimension." ${ }^{62}$

4. Limitations of Research on Community Service. While there has been a steady increase in research on community service programs, it has not been entirely problem-free. ${ }^{63}$ Partly, this is due to the use of inadequate research designs, such as the lack of control or comparison groups, "small sample sizes," and the grouping of numerous different types of service activities under the single independent variable of community service. This single variable does not take into account that the service activities vary from long-term to short-term, voluntary to mandatory, and for-credit to no-credit. For example, Yates and Youniss argue that the tendency of large-scale surveys to "generalize across a variety of programs and activities explain[s] why these studies find only modest effects." Also, according to Wade and Saxe, "there is inconsistency in virtually all outcome areas [which] can be explained in part by the [presence or absence] of a reflection component and [the amount of] time spent on service, [the quality of the program studied,] and differences in student characteristics. ${ }^{\circ 6}$ Further, Yates and Youniss advocate research that focuses more on "the process of participation" than on the participants' characteristics and the impact of service. ${ }^{67}$

\section{Program Elements and Processes}

In addition to the purposes of community service, the program structure and processes by which community service takes place affect the program activities and the experiences of the students. ${ }^{68}$ For example, Rebecca Carver points out that the "characteristics of the educational programs and the characteristics of the setting" influence experiential education and ways by which adolescent de-

59. See Richard G. Niemi \& Chris Chapman, The Civic Development of 9th Through 12th Grade Students in the United States, U.S. Department of Education, vi 1996 NCES 1991-131, at 59 (1999).

60. See Root, supra note 12, at 49.

61. Yates \& Youniss, supra note 11, at 272.

62. Wade \& Saxe, supra note 43 , at 346.

63. See Kraft, supra note 11, at 143.

64. See id.

65. Miranda Yates \& James Youniss, A Developmental Perspective on Community Service in Adolescence, 5 SOC. DEV. 85, 98 (1996).

66. Wade \& Saxe, supra note 42 , at 345.

67. Yates \& Youniss, supra note 65, at 97.

68. See Rebecca L. Carver, Theoretical Underpinnings of Service Learning, 36 THEORY INTO PRACTICE 143-49 (1997); Furco, supra note 24; Root, supra note 11. 
velopmental needs are met. ${ }^{69}$ These include activities, such as recruitment, training, supervision, recognition, and evaluation of students, the opportunity for students to reflect on their experiences, whether or not the community service activities are required, and the collaboration between the school and local organizations where students serve. A survey of administrators revealed that the most nettlesome aspects of implementing service requirements are "mentoring and supervising student activities, ... evaluating students, and [issues associated with] . . transportation.","

1. Program Structure and Components. The literature on the recruitment of young volunteers sheds light on the recruitment of students into school service programs. A national survey of teenagers showed that being asked to volunteer by someone, such as a friend, teacher, or relative, was the most common way by which they learned about volunteer opportunities. ${ }^{71}$ Similarly, the Do Something, Inc., survey suggests that young persons are more likely to volunteer if they learn about the opportunity from someone they know. ${ }^{72}$

Yates and Youniss underscore the importance of site supervisors who serve as "models of moral commitment who offer their perspective on social problems and the dynamics of trying to alleviate these problems." "73 Furco has proposed twelve "programmatic issues" inherent in youth service programs: availability of "appropriate service opportunities, service program requirements, assessment of student work, rewards for student service, recruitment of students, marketing to promote the program, transportation options, student safety, teacher roles, program funding, program flexibility and change, and program evaluation." ${ }^{74}$ However, as useful as this list may be, little empirical research has focused on these kinds of program elements.

The extent to which a community service program receives institutional support may also contribute to its climate and student experiences. This support includes commitment by the board of education, principal, and teachers through allocation of resources to program activities, ${ }^{75}$ the integration of service into the regular curriculum, ${ }^{76}$ and acknowledgment of student service by school

69. Carver, supra note 68 , at 146.

70. National and Community Service Coalition, supra note 8 , at 3.

71. See Virginia A. Hodgkinson \& Murray S. Weitzman, Giving and Volunteering AMONG AMERICAN TEENAGERS 12 TO 17 YeARS OF AGE 23-24 (1996).

72. See Princeton Research Associates, Organizations Survey-Overview: Community Organizations Use of Young People as Volunteers. Report of a National Survey of Community Organizations that use Volunteers (Mar. 6, 2000) <www.dosomething.org/connections/research/paper2/default.htm>.

73. Yates \& Youniss, supra note 65, at 145.

74. Furco, supra note 24, at 406.

75. See California Department of Education, supra note 19; HARRISON, supra note 29; Susan Schwartz, Encouraging Youth Community Service: The Broadening Role of High Schools and colleges, 76 NAT'L CIVIC ReV. 288, 292 (1987); Rahima C. Wade, Community Service Learning and the Social Studies Curriculum: Challenges to Effective Practice, 88 SOC. STUD. 197, 199 (1997); Youth Service California, supra note 21, at 52.

76. See Rutter \& Newman, supra note 35, at 373; Kraft, supra note 11, at 141. 
officials as a worthwhile activity. ${ }^{77}$ Also, according to Wade, an environment supportive of service learning includes professional development opportunities for teachers and staff and the provision of time for them to plan, coordinate, collaborate, and evaluate service-learning activities. ${ }^{78}$

2. Reflection. According to several observers, another key component in shaping the community service activities in a school-based program is one that encourages students to reflect (either through written assignments, discussion, or artistic expression) upon their service experience in relation to their academic work, personal values and beliefs, social responsibilities, and career interests. ${ }^{79}$ D.T. Moore discovered that "reflection-thinking about experiences in broad terms-occurred occasionally ... but not as often as desired." ${ }^{\text {" }}$ Based on their 1984 national survey of schools with community service programs, Robert Rutter and Fred Newman called for a "reflective seminar that focuses directly on issues of social responsibility." Westheimer, asserting that service learning should focus on change rather than charity, argued that much student reflection lacks "the kind of critical analysis that might help students step outside dominant understandings to find new solutions." ${ }^{2}$ Youniss and Yates concluded that the written reflective component of a service program in a parochial high school contributed to the students' sense of personal identity, moral reasoning, and political agency. ${ }^{83}$

A study by the U.S. Department of Education revealed that more than half of the students (fifty-six percent) involved in community service "reported that their schools in some way used service-learning methods by incorporating their community service into the curriculum" and slightly less than half (forty-five percent) reported that they had the opportunity to talk about their experiences in class or small group discussions. ${ }^{84}$ Less than one-fifth reported that the school required them to write about their service experience. The study also shed light on the relationship between school practices to promote student community service and incorporation of community service in the curriculum. Students attending schools that did the most to promote community service were most likely to report that they talked about their community service in class. ${ }^{85}$

77. See Schwartz, supra note 75 , at 292-93.

78. See Wade, supra note 75, at 198-99.

79. See Kraft, supra note 11, at 140; Suzanne Mintz \& Goodwin Liu, Service-learning: An overview, reprinted from Corporation for National Service, National and Community Service: Roles for Higher Education, Mar. 1994, at 14; Root, supra note 12, at 52-53; Rutter \& Newman, supra note 35, at 373; Wade \& Saxe, supra note 42, at 345; Wade, supra note 75, at 197; Yates \& Youniss, supra note 65, at 95-96.

80. D.T. Moore, Students at Work: Identifying Learning in Internship Settings (1982), in Schumer \& Belbas, supra note 24, at 218.

81. Rutter \& Newman, supra note 35 , at 373.

82. Kahne \& Westheimer, supra note 39, at 598.

83. See YOUNISS \& YATES, supra note 43.

84. See U.S. Department of Education, Mary Jo Nolin et al., Student Participation in Community Service Activity, NCES 97-331, at 24 (1997).

85. See id. at 25. 
However, the opportunity for reflection may not have the expected positive impact. Another national survey on civic development of ninth- through twelfth-grade students revealed that whether or not students' service experiences were integrated into their courses through class discussion, writing about them in a journal or essay, or having service as part of the course grade, did not make a difference in their civic development scores. Therefore, the opportunity for reflection and integration was not positively correlated with students' political knowledge, discussions with parents about politics, making a public statement, or understanding politics. ${ }^{86}$

3. Mandate. Although many private schools, especially those with religious affiliations, have required community service for several years, numerous public school districts, in more recent years, have also begun to require their students to participate. The most prominent example occurred in 1992, when Maryland's state legislature passed a law requiring all public high school students to complete seventy-five hours of community service in order to graduate. Unsuccessfully challenged in local courts, the Supreme Court refused to hear a case asserting that required community service violates student rights and represents "involuntary servitude," thereby allowing mandated public service. ${ }^{87}$ Even though it is a controversial issue, a limited amount of research has been published regarding the effects of required high school community service.

Arthur Stukas and his colleagues found that, among college students who were required to participate in a service activity, those who felt they were being controlled were less likely to intend to volunteer in the future than those who felt predisposed to participate even though required ${ }^{88}$ Miller found that high school girls are more supportive of required service than boys, because the former tend to focus on the need for volunteers while the latter tend to focus on the mandatory aspect. ${ }^{89}$ In a study of civic development among high school students, no difference was found in levels of civic development between high school students in programs that required or arranged service and all other students: Both tended to lead to changes in civic development. ${ }^{90}$

4. Collaboration between School and Community Organizations. To a large extent, the success of a high school community service program depends on "community partnerships" $"$ and whether community organizations are available

86. See id. at 59.

87. See Dundjerski \& Gray, supra note 9, at 30; see also Rodney A. Smolla, The Constitutionality of Mandatory Public School Community Service Programs, 62 LAW \& CONTEMP PROBS. 113 (Autumn 1999).

88. See Arthur A. Stukas et al., The Effects of "Mandatory Volunteerism" on Intentions to Volunteer, 10 PSYCHOL. SCI. 61 (1999).

89. See Fayneese Miller, Gender Differences in Adolescents' Attitudes Toward Mandatory Community Service, 17 J. ADOLESCENCE 381, 381-93 (1994).

90. See U.S. Department of Education, supra note 84, at 58.

91. McPherson \& Nebger, supra note 34, at 332; Mintz \& Liu, supra note 79, at 14. 
and willing to serve as sites for student volunteers. Schools rely heavily upon these local organizations, agencies, and groups to work collaboratively with them in the education of their students, not only through the provision of a safe site for the students' service, but through supervising, mentoring, and training their students. Furthermore, through student participation in local organizations, community perceptions of students and schools may improve and, consequently, increase the demand for local partnerships. ${ }^{92}$

In exchange for taking the students, the community organizations benefit by supplementing their labor force in a relatively inexpensive way, meeting community needs, and contributing to the likelihood that students will volunteer in the future..$^{93}$ An evaluation of K-12 service-learning programs in fourteen California schools found that "service-learning activities met real community needs and generated increased community demand for student service." 94

Despite the benefits of student volunteers to local organizations, collaboration between the schools and community organizations can be difficult to initiate and sustain. For example, Carl Fertman points out that partnerships with community agencies are "not always easy" because of legal, structural, financial, and cultural differences. ${ }^{95}$ From the school's perspective, to hand over the responsibility for students to outside groups may create anxiety over student safety, as well as a fear of loss of control. ${ }^{96}$ From the viewpoint of the community organizations, some agency leaders (twenty-eight percent) view younger volunteers as being less reliable than older ones, requiring too much supervision, and not warranting training because of high turnover. ${ }^{97}$

When schools require community service, creating an even greater demand for service sites, this availability and willingness to collaborate becomes even more critical. If schools do not have sufficient resources to implement the service programs, they may "end up expecting charities and students to make the community service projects worthwhile ... and the student volunteers bec ome burdens." ${ }^{\circ 8}$ An additional problem from the perspective of local groups is that they may not be consulted for their ideas by the schools when they create new community service programs. ${ }^{99}$ Maybach has been especially critical of the "student-only focus" of service-learning projects and has proposed an alternative model that seeks to create a partnership between student and recipient in

92. See California Department of Education, supra note 19, at 3.

93. See Rahima C. WAde, Community Service LeARning A Guide to InCluding Service IN The Public School Curriculum 48-49 (1997); Peggy Odell Gonder, Exchanging School and Community Resources, in COMMUNITIES AND THEIR SCHOOLS 321 (Don Davies ed., 1991).

94. California Department of Education, supra note 19, at 3.

95. Carl Fertman, Creating Successful Collaborations Between Schools and Community Agencies, 22 CHILDREN TODAY 32 (1993).

96. See Gonder, supra note 93, at 328.

97. See Princeton Research Associates, supra note 72, at 3.

98. Dundjerski and Gray, supra note 9, at 30.

99. See id. at 31. 
goal-setting to include the perspective of the service recipients in planning and implementing the programs. ${ }^{100}$

\section{E. Student Perceptions}

Although student assessments of their community service experiences are another significant component in understanding community service, little research is available that reports their perceptions and judgments. In a review of the literature regarding characteristics of individual experiences, Susan Root found that criteria such as whether or not "they have adult responsibilities at their sites, maintain collegial relationships with site staff, make a significant contribution, and are challenged" will determine the impact of their service experience. ${ }^{101}$ Do Something, Inc.'s survey of young persons fifteen- to twenty-five years old revealed that they considered the following factors to be the most important in determining their satisfaction with their service experience: having an important responsibility, working with inspirational leadership, understanding what is expected, having the opportunity to be involved in important decisions, seeing the results of their participation, and gaining valuable career-related experiences. ${ }^{102}$ Robert Wuthnow concluded from his analysis of sixty in-depth interviews with teenagers, primarily high schoolers, that the aspects of service they like most are a meaningful experience, making a difference in another person's life, personal contact, feeling appreciated, taking initiative, and pride in what they do. ${ }^{103}$

Not all community service experiences are satisfactory. The Do Something, Inc. survey found that sixteen percent of the sample indicated they did not have a good experience. ${ }^{104}$ Two frequently cited reasons were disorganization of the group or a lack of clear expectations and a lack of respect for their supervisors or others with whom they worked. ${ }^{105}$ Wuthnow found that the aspects of volunteering disliked by teenagers include the amount of time devoted to bureaucratic rules and regulations that prevent direct contact with people in need. ${ }^{106} \mathrm{~A}$ survey of teenagers found that while nearly all of them believed "it is important to learn the value and importance of community service, only ... forty percent say their schools convey that message well."107

100. Carol W. Maybach, Investigating Urban Community Needs: Service Learning From a Social Justice Perspective, 28 EDUC. AND URBAN SOC’Y 224, 227 (1996).

101. Root, supra note 12, at 52.

102. See Princeton Research Associates, Youth Survey: Young People's Community Involvement. Report of the Findings 1 (Mar. 6, 200) <www.dosomething.org/connections/research/paper1/default. htm>.

103. See ROBERT WuTHNOW, WHAT IT MEANS TO VOLUNTEER: LESSONS FROM AMERICA'S YOUTH 16-19 (1995).

104. See Princeton Research Associates, supra note 102.

105. See id.

106. Wuthnow, supra note 103, at 19-20.

107. The Prudential, Highlights of the Prudential Spirit of Community Youth Survey, Oct. 16, 1996 (Mar. 6, 2000) <http://www.prudential.com/community/sci4.html $>$. 
III

\section{CASE Study In Los ANGeles CounTy}

To further elaborate the current state of high school community service programs, this section presents the findings from the authors' three-year study of high school community service in Los Angeles County, one of the most diverse areas in the country. The definition of community service used in this research includes any service activity recognized or sponsored by the school, regardless of where it occurs or how long it takes.

\section{A. Overview of the Study: Methods}

This study of high school community service programs in Los Angeles County was a three-phase multi-method project. The first phase included a mail survey of 385 public and private high schools in Los Angeles County regarding their community service programming and in-depth interviews with administrators and faculty of eighteen schools in six areas. ${ }^{108}$ The second phase of the study focused on the roles and perspectives of community organizations for which students volunteer and involved in-depth interviews with representatives of eleven community organizations and eighty-four mail survey responses regarding the role they play with secondary schools, their perception of the benefits and costs of student participation, problems they encounter, and best practices. ${ }^{109}$ The final phase of the study concentrated on the third actor in school community service projects: the students, who comprise an essential, though rarely consulted, resource for the improvement of community service programs. Two-hundred eighty-five students from twenty-two schools in seven areas were interviewed for their descriptions and assessments of their high school community service experiences.

Seven communities were selected to represent the diverse socioeconomic and cultural areas within Los Angeles County. At least three schools in each area were selected for inclusion in the school administration and student interview phases of the project; the schools in each area include at least one private and one public school, ideally including one public, one private religious, and one private nonsectarian school.

Overall, we found sponsorship of the school-in other words, whether it was public, religious, or nonsectarian-to be the most important factor in explaining differences in the findings. However, this is correlated with the location of the school and the diversity of the population. Nonsectarian schools are primarily suburban or outside the central city and have the highest economic status and a predominantly white student population. There are no nonsectarian schools in two of the areas selected-the two areas with the lowest socioeconomic status. The public

108. See Sally Raskoff \& Richard Sundeen, Youth Socialization and Civic Participation: The Role of Secondary Schools in Promoting Community Service in Southern California, 27 NONPROFIT \& VOLUNTARY SECTOR Q. 66, 72 (1998).

109. See Sally Raskoff \& Richard Sundeen, The Role of Community Organizations in the Promotion of School Sponsored Student Volunteering (paper presented at the ARNOVA Meetings, Indianapolis, Dec. 3-5, 1997). 
schools are located in either primarily white, middle- to high-socioeconomic suburbs or inner-city areas with low or mixed socioeconomic status and a racially diverse or primarily Latino or African-American student population. The religious schools are represented in most areas, although they tend to be located in areas with low or mixed socioeconomic status.

\section{B. The High Schools}

1. Prevalence of Community Service Programs. In Los Angeles County, more than eighty-two percent of high schools have community service opportunities for their students. ${ }^{110}$ While public schools send more students into their communities to do service, private religious schools send a higher proportion of their students into service activities. This pattern is related to the larger size of public schools and to the encouragement the religious schools give to their students. The religious schools often incorporate the service into their coursework, particularly religious courses, thus ensuring that most students will participate in service at some time before their graduation and will learn certain ethical and religious ideals connected to such service.

2. Program Elements. Community service programs may or may not be mandatory. Some schools do not require students to do service, yet they give them the option to receive elective or class credit for service. The religious and nonsectarian private schools are more likely than public schools to require community service of their students. Furthermore, both types of private schools have greater proportions of their students involved in community service programs, regardless of whether service is required or optional. ${ }^{111}$ Nevertheless, differences exist between the two types of private schools. For example, a larger proportion of students in nonsectarian schools (eighty percent) than religious schools (seventy-three percent) participate in service, although a greater proportion of religious schools than nonsectarian schools require some type of community service. These differences represent differences in educational missions and the demands of their respective parent and student constituencies. Among religious schools, community service rests upon biblical commands and theological ethics that emphasize service to others and personal, moral, and spiritual growth.

The nonsectarian schools are the least likely to offer a community service program, and their support appears to rest on the personal development of social responsibility for the less fortunate, as well as the perceived importance of service to college admissions. A substantial proportion of those nonsectarian schools that do not require service hold that service is not a legitimate form of academic activity. Consequently, they may expect their students to undertake service independent of school or encourage such service activities through clubs.

110. See Raskoff \& Sundeen, supra note 108 , at 73.

111. See Appendix Table 1. 
Several schools do not seem to be concerned with how students might integrate the multiple objectives or tie their service experience into their academic curriculum. A few schools require students to keep journal accounts of their service experiences, but fewer schools actually use the journals as the basis for discussions between students or with a teacher or as reflections about the readings assigned in the class. Other schools show little evidence of attempts by teachers or administrators to develop community service programs designed to meet educational goals.

3. Rationale. Schools support student community service activities for many reasons. In our interviews, school personnel offered the following program rationales: (1) personal growth, which includes career-job exploration and training, well-being and self-esteem, and responsibility; (2) educational development, such as experiential education, and multicultural understanding; (3) community involvement including community understanding, improvement, and change; and (4) altruism, both religious and nonreligious.

The diversity of program rationales reflects the various educational purposes and interests of different types of schools. The religious and nonsectarian schools tend to emphasize the importance of ethical responsibility and personal development, while public schools tend to stress community involvement, career development, and personal development. A potential problem emerges when multiple goals of community service programs exist in a single school; for example, the objective of community involvement may be inconsistent with the goal of career development. School community service programs that appear to be well run and oversee large numbers or proportions of students generally have two or more of the following characteristics: supportive and committed school administration and board, faculty, parents, and community groups; a staff member serving as a director or coordinator of community service activities; integration of service activities with academic goals; and financial resources dedicated to the activities. ${ }^{112}$

\section{Relationships between Schools and Community Organizations}

The community organizations that provide a setting for school-based student volunteer service include public and parochial elementary and middle schools, municipal governments, health clinics, playgrounds, Chambers of Commerce, police departments, church-affiliated programs, youth groups, and environmental conservation organizations. They range in size from very large public hospitals to small nonprofit operations. A mail survey ${ }^{113}$ of community organizations identified as student sites showed that nearly three-fourths are nonsectarian, nonprofit organizations; eleven percent are organizations under religious auspices; eight percent are public agencies; and six percent are for-

112. See Furco, supra note 24, for a useful conceptual framework for youth service programs.

113. One hundred thirty four organizations were randomly selected from a list of more than 600 community agencies to receive a copy of the mail survey. Eighty-four were returned, with 63 completing the questionnaire and 21 indicating they no longer used high school volunteers. 
profit companies. The most common areas in which these organizations operate are mental health, social services, youth development, community safety, and fundraising.

1. Satisfaction and Collaboration. The community organizations are more concerned with volunteer assistance with their workload and fostering relationships within the community than more specific goals relating to management responsibilities within the organization. Organizations perceive the most important benefits from the use of high school volunteers to include labor for the organization, community relationships, and service to clients. On the other hand, the organizations find the least important benefits to include efficiency, resources, and publicity.

According to the community organizations' representatives, a collaboration will be effective if the organization is satisfied with its relationship with the high school, perceives that it would benefit from using student volunteers, and has a mutual understanding of the goals of the other organizations involved. However, less than half of the representatives report perceiving that these forms of collaboration have been achieved.

2. Problems. Community organizations may find it difficult to develop ongoing relationships with schools, particularly if a school does not identify one of its staff as a liaison for service programs, or if a staff member does not belong to a local organization. However, barriers to forming such relationships result from an overload of teacher's work responsibilities, because many teachers face crowded classrooms with declining or deteriorating resources. School personnel often perceive service projects as an addition to their busy schedules and, consequently, may avoid them. School personnel often do not know that the community organizations provide the training and supervision necessary.

Besides problems of collaboration, questions of liability and transportation also confront community organizations. While liability issues are important to both schools and community organizations, responsibility often rests with the community organizations, because the volunteers are located in their workspace. Those agencies that require training prior to volunteering activities and require students to volunteer a certain number of hours often carry liability insurance for their volunteers. The smaller organizations, in which the volunteering is more episodic than regular, frequently cannot afford the costs of this insurance.

Transportation also remains a major obstacle to off-campus community service. One agency director's concern for students who use public transportation from the site led her to prohibit service opportunities after dark to those without private transportation. Schools may provide transportation for episodic largescale activities, yet may not be able to afford to assist individual or small groups of students on a regular basis. One exception to this was a private, nonsectarian school where parents assume responsibility for taking weekly service groups to their respective sites and discussing the experience with the students while returning to the school. Community organizations are not equipped to transport 
teenagers who may not have driver's licenses. Transportation problems directly affect the services a school sponsors.

3. Conclusion and Summary. Improved communication between schools and community organizations regarding specific responsibilities would clarify the steps necessary for student service to occur. Communication between school and community organizations should focus on the school's educational goals and community service objectives so that the organizations can help implement those goals when working with the students. For schools, community organizations serve as allies-sometimes unrecognized-in meeting educational objectives. Organizations are often willing and able to train and supervise student volunteers and might even provide liability insurance, although schools are often unaware of this. Improved collaboration between schools and organizations that welcome teenage volunteers is essential to viable long-term community service programs. While it is important that community groups be assisted in reaching their objectives, the broad educational goals remain paramount. Schools could strengthen the educational aspects of their service programs by sponsoring workshops for community organizations, which could clarify the role of service in secondary school curricula. Municipal government volunteer bureaus, nonprofit volunteer centers, or organizations devoted to creating and sponsoring service projects may serve as central coordinating bodies for local secondary schools that do not possess adequate staffing.

Community organizations and schools have complementary interests in promoting community service activities. In return for allowing students to participate and pursue their educational goals, community organizations receive free or low-cost assistance in carrying out their missions. Student volunteers also serve as a potential source of future employees, volunteers, and donors to these or similar organizations. Nevertheless, barriers to collaboration exist, including problems of liability, transportation, workload, differences in interests, and practical evaluation.

\section{Student Perspectives}

The purpose of this phase of the research project was to gain insight into the students' roles and perspectives on their community service experience. Specifically, we focused on (1) the activities students carry out; (2) the students' perceptions of encouragement they receive to participate in service and to connect their service with their learning; (3) their perceptions of the organizational structure or program elements that relate to community service; (4) the students' assessment of their service involvement; and (5) their perceptions of the impact and outcomes of community service on themselves.

In general, the student interviews yielded much information that was not forthcoming in the school and community organization phases of research. The students, drawn from a wide variety of cultural backgrounds and levels of involvement in school activities, expressed overwhelmingly positive attitudes 
about their community service experience. Although some students were not familiar with community service activities (other than those mandated by the justice system), most (eighty-two percent) had done some community service prior to our interview. The findings below refer to the community service activities related to their high schools, unless otherwise stated. ${ }^{114}$

1. Activities. As mentioned previously, the students' service activities take place in a variety of organizations: their own schools, other schools in the area, nonprofit and public organizations, and local businesses. Slightly less than onethird of the students reported doing service at their own schools and slightly more than twenty percent reported that their service occurs in schools other than their own. Others serve in hospitals and other medical care organizations (ten percent); churches, religious organizations, and community service organizations (six percent); governmental agencies (four percent); residential programs, homeless projects, and sports programs (three percent); and miscellaneous others (eleven percent). ${ }^{115}$

Students in the public schools are more likely to do their service activities in their own schools, while the students in nonsectarian and religious schools are more likely to volunteer in nonprofit organizations. Students in all schools are equally likely to volunteer in other schools, such as local elementary and middle schools.

Differences also exist in the tasks and duties students perform. The responsibilities and activities most often reported were (1) collection, preparation distribution, and serving of goods to the homeless; (2) tutoring/literacy assistance; (3) clean-up, painting, or grounds maintenance; (4) patient assistance in medical settings; and (5) teacher's or librarian's aide. Students carry these activities out in various ways, including through direct service, events, leadership activities, assisting professionals in their work, fund raising, indirect service, and maintenance work. Most students participate in either direct or indirect service activities, working with the people who benefit from the service, such as children and elderly persons, or working in an office or business setting with computers or paperwork.

Students in the three types of schools differ in their types of service activities. A greater proportion of nonsectarian school students work directly with clients or in leadership activities, while more religious school students provide indirect service, such as office work. Students in public schools are more likely to do fundraising, such as dance-a-thons and AIDS walks, although differences between suburban and inner-city schools exist. The inner-city public school students are more likely than other students to do maintenance work, such as painting and clean-ups, for their service activities. These differences among suburban and inner-city school activities appear to be related to class level and community/school re-

114. Many students reported community service activities with their families, churches, and former schools, both elementary and middle or junior high schools.

115. See Appendix Table 2. 
sources, became the physical condition of many inner-city schools requires more resources for maintenance than are available.

The responses suggest a relationship between the type of activity performed and sources of enjoyment from the experience and levels of satisfaction with community service. There tends to be a positive association between students whose work assists professionals or takes the form of direct service and the likelihood that students will report enjoyment of the service orientation of their work. Students do not perceive fundraising, indirect service, leadership activities, or doing maintenance work as service-oriented. The findings suggest that direct service is the most popular type of work and carries high levels of satisfaction with community service.

2. Encouragement to Participate. The recruitment of students to participate in community service depends, in part, on the extent to which students feel encouraged and supported in these activities. More students feel encouraged to do community service by their schools than by other institutions or groups, particularly those in private religious schools. ${ }^{116}$ Specific people or school groups who encourage students include teachers, counselors or other staff members, community service representatives, and clubs.

A substantial proportion of students (twenty-four percent) responded that they receive encouragement from no one, often claiming that they were selfmotivated, like one religious school student: "I just want to do community service because I want to help somebody else." A student at another religious school claimed to perform service out of guilt because "everyone else is doing it [and] I don't want to sit at home." A third emphasized the serendipitous nature of becoming involved in service: "One day I just seen [sic] this guy painting and went out there and helped out."

Among those students who did not feel encouraged, differences exist between the students from the three types of schools. Public school students attending schools in the inner city reported less encouragement than those attending schools in more affluent areas. Moreover, students attending schools that require community service are more likely to perceive encouragement by the school. ${ }^{117}$

Generally, students may receive encouragement from three sources: familial support, personal or self-oriented opinions and attitudes, and external support. External sources are most prevalent and include being exposed to community service by example or direct communication. Many students perceive encouragement as being asked or told to do service, discussing it with friends, being rewarded with praise, and seeing others volunteer. One student disclosed he felt encouraged by his ROTC instructor's threat of demotion.

116. See Appendix Table 3.

117. Although some students indicate that encouragement often takes the form of merely reminding them to "get their hours." 
3. Encouragement of the Connection between Service and Learning. That students should be encouraged to relate their experience to the educational objectives of the school stands as one of the core tenets of most experiential forms of learning, including school-based community service. Consequently, as a means of exploring one facet of service learning, we asked students whether they felt encouraged by the school to think about the connection between their service experience and learning in the classroom.

More than one-third of the students claimed they did not feel encouraged to think about the relationship between their community service and learning in the classroom. ${ }^{118}$ Although most of these students did not offer an explanation, some said the school only provided information regarding opportunities (without encouragement) or pushed them to fulfill their hours. Others claimed they were self-motivated and did not need encouragement; a few stated that service and classroom were entirely separate.

Among those who replied they felt encouraged to make the connection between service and classroom, the largest proportion of students declared that the school accomplished this through school situations or activities, including planting trees, field trips, writing assignments, specific classes, such as English, religion, or a community service class, friends, and school clubs and organizations. For example, a student at a nonsectarian school stated that teachers "encourage me to take what I learn [and] take it to these kids, show them a good example, like how to behave, and be nice to other kids. I think that is how they encourage us."

A smaller group described service learning activities in particular, such as writing assignments, discussing their experiences in class, applying what is learned, and learning to work with others through the service experience. In an English class, one student noted that the teacher "made us write a journal about it. It makes you think about [being] help to other people. Another student observed that her biology class also encouraged service learning: "We help others plant trees and the teacher said we could do an essay on the community service experience, kind of like extra credit."

4. Organizational Elements. A community service program's structure and components, including training, supervision, evaluation, and recognition, can shape the quality of the students' experiences. While eighty-six percent of the students receive supervision in their community service activity, only slightly less than half receive training and evaluation, and slightly more than one third receive recognition for their community service activity. ${ }^{119}$ Many students acknowledge that programs need to be better organized and to include greater amounts of training and evaluation.

Training ranges from intensive, formal orientation, such as three-day training sessions in hospitals, to more informal, on-the-job instruction. Among those

118. See Appendix Table 4.

119. See Appendix Table 5. 
not receiving training, some felt it was not necessary. Students from the urban areas and minority backgrounds mentioned more training, evaluation, and recognition, but less supervision than students from suburban, white majority, and higher-status backgrounds. This suggests that either schools more actively mentor the higher status students and give them more autonomy than the students from lower-status areas, or they give the higher-status students less complex tasks. Supervisors tended to be school personnel, parents, employees or volunteers at the community organizations where the service activities occur. Students at the nonsectarian schools, probably because they tended to have offcampus service locations, were more likely to receive supervision by a community organization representative.

Types of evaluations ranged from written records, including sign-in sheets, supervisors' reports, self-assessments, and letters or certificates, to verbal or informal evaluations. Some of those without any apparent organizational assessment stated they have "ways" of knowing whether they perform satisfactorily. These "ways" relate to feelings of competence and efficacy or to a lack of negative feedback. As one student said, "Well, I'm sure they would make certain we wouldn't be harmed. We wouldn't be harmful towards others. . . Of course, you're not going to [be with] some blind person and be mean to them or something like that." Another student stated that the volunteer supervisor "really provides jobs for us based on what we've done in the past, how we've done it," even though there was no formal written evaluation. Students who reported no evaluation mentioned that the lack of evaluation seemed to indicate a lack of support for the activity. A student reported that, at her school, "[t]hey collect hours, how many hours people put in. You have to put in [fifteen] hours a year, it's hardly anything. But they don't really care how you do that. They don't make any notes [as to] how you do that."

The means through which students receive recognition for their service varied from participating in formal presentation ceremonies to receiving informal benefits. They consisted of tangible items, such as certificates, plaques, medals, trophies, and letters, and intangible ones, such as verbal acknowledgment of their work. In some cases, students received recognition from the service site, such as a certificate and party provided by a large hospital to all volunteers. In other cases, the school provided recognition, such as a school assembly where students receive awards based on the number of service hours they perform. Students not receiving any form of recognition often stated that this "was not important" to them.

Students had very specific opinions about the structure of the community service programs in which they participated. When asked what the most important element in their service experience was, students' responses included a positive attitude, service provision, helping others, sufficient time, having fun, organizational details, such as teamwork, and specific program features. With respect to attitudes, the students recognized that an ideal situation involves coming to the service activity with a positive attitude, commitment, dedication, 
responsibility, awareness, an open mind, a friendly disposition, respect for the clients, seriousness, interest, kindness, and unselfishness.

Students mentioned that service itself is important: doing hands-on service, working and communicating directly with clients, ensuring that "enough" people participate in the service activity, and seeing the outcome or results of their work. An emphasis on helping indicates that the service program supported or motivated students actually to do service and help others. Organizational details are important, such as teamwork or work that fosters a "group feeling" and the need for activities to be organized prior to the arrival of the participants. Specific features of service programs included receiving credit, food, or money, accessible location, adequate resources, rest, transportation, a range of activities, learning helpful things, going places, and better training and supervision. Also important is having enough time to participate or offering the service at a good time, having fun or enjoying the service, doing the service willingly, and getting some reward from the activity whether it be a thank-you, smile, or selfawareness.

\section{Student Assessments}

a. Positive experiences. To tap into students' assessments of their community service, we asked them to indicate what they liked most and least about their community service. The interview schedule also contained questions regarding any fears or concerns students had about their service experience. Overall, they expressed very positive assessments about their high school service experiences. ${ }^{120}$

The largest number responded positively to the service or helping aspects of their community service activities. They particularly liked the elements of service orientation and helping others, the opportunity for social interaction, a sense of accomplishment, and learning about careers, the community, and themselves. They reported liking to help others, seeing the consequences of their service, and feeling good and appreciated for their work. For several students, an important element of service orientation included working with children. Typical of these responses is the following: "I liked to sit down and read with the kids. I liked to be at the playground with them."

Another important source satisfaction for teenagers was the opportunity for social interaction: being with friends, meeting new people, participating in a friendly environment, and having fun. For example, one student said, "I really like being able to do other things with people besides just your friends and talking to other people you don't know yet." Some of them also noted the feelings of closeness or unity that service brought to them. Others most liked the learning that occurred through their service activities-not only the new experiences, but information about careers, the work of teachers, the community and themselves. One student expressed his opinion in the following way: "It's

120. See Appendix Table 6. 
giving me a lot of training and I am looking forward to a career in there, in the hospital." A student at a nonsectarian school declared that she "can feel much differently about myself, and you know a lot of times I find negative aspects in myself when I do community service, because I don't like the way I am, and a lot of times it changes the way I think and the way I act."

When comparing positive assessments among types of school, one of the significant findings is that students from nonsectarian schools are more likely than others to be satisfied with the service dimensions of community service, while public school students are the least likely to be satisfied. This may be the result of the types of service performed by students at each type of school. Students who do direct service are more satisfied than those who do indirect service, and students in nonsectarian schools are more likely to do direct service than others.

b. Negative experiences. Responding to the question of what they liked least, one-fifth of the students assert that they disliked nothing about their experience. ${ }^{121}$ Some, as the following comment indicates, evolved from critic to supporter as a result of their participation: "I always thought it was going to be work and I would say I don't want to go. But then when I was there, I would do it and I didn't want to leave cause it was fun; it wasn't work." Among those aspects of community service that students liked least, problems with conditions at their school and service sites, such as school policies and rules, the lack of transportation, disorganized service sites, and shortage of staff, were the most frequent category. For example, some students found the hour requirement distasteful: "I don't like why we have to have a certain amount of time. I mean, I liked that they want us to do it, because I know that lots of people wouldn't do it without having that. But sometimes you really don't have time." Also, other specific time issues emerge: too much time spent, waking up too early, and not enough time spent on volunteering. Personal issues are troublesome for some students, for example, tiredness, personal discomfort, such as not liking the food at the service site, and personal shortcomings.

Many students identified several dimensions of inefficacy or disappointment with community service: They disliked being bored, not making a difference, not feeling appreciated or recognized, being required to serve, not receiving pay for their work, sensing a lack of commitment by others toward volunteerism, having to do too much work, and doing specific types of work, such as cleaning up. Also, people who were annoying and the presence of people in need or suffering were a concern for some students.

The most striking finding regarding differences among types of schools is that the smallest proportion of students to indicate they were dissatisfied with nothing came from nonsectarian schools. Although not bothered by specific school or site conditions, they are more likely than students from the public or religious schools to dislike the time demands of service, having a sense of per-

121. See Appendix Table 7. 
sonal inefficacy doing service, interacting with annoying persons, and seeing suffering.

c. Fears and concerns. In reporting their fears and concerns about community service, almost half of the students said they possessed none. ${ }^{122}$ Some of these students elaborated upon their reason for saying they had no fears or concerns, noting that they were ready, aware, and experienced in service activities; they were excited to do it; they felt safe; they did not know what to expect so they were not afraid; and, since it was required, they would give it a try.

Among the responses that indicate some fear, the students most frequently admitted the fear of making mistakes and the fear of being rejected in their service activities. Nonsectarian school students showed the greatest concern about the former and religious school students about the latter. Neither of these concerns appears unusual for adolescents who may find themselves in new or different environments. One might speculate that nonsectarian, privateschool students may be high achievers and feel pressures to succeed more acutely than other students, while religious school students, in bringing a particular religious point of view to a service activity, may have concerns about being accepted by persons of other faiths. Another small group of students identified specific places, things, or situations that create a sense of fear, such as homeless people, urban neighborhoods or streets, gangsters, and dogs, as well as getting sick and having something injurious happen to those being served. A few students had concerns about having a negative experience or being overly involved. Other types of concerns centered on time (not enough or getting enough to fulfill the requirement) and other more idiosyncratic reasons (seeing people in pain or parents' anger over the amount of time spent on community service by the student). A theme heard in some responses is that the student's initial apprehensions did not materialize:

In the beginning, I didn't know what to do. But then, after beginning there every day with the patients, it was really nice. I got to know the people. And I talked to this lady and who told me about her past; it was interesting ... like a book couldn't teach you.

6. Impact or Outcome. The students responded to a set of questions regarding what they had learned from their community service experience and what their future intentions were for volunteering in community service. The students' responses in these areas reveal two dimensions of how they perceived the personal impact of their service participation.

a. Lessons learned. The majority of the students indicated that they learned about themselves and about helping others in their community service experience. $^{123}$ Students learned about their own attributes, self-image, and

122. See Appendix Table 8.

123. See Appendix Table 9. 
competencies: "I learned about myself a lot, what type of a person I am. I mean I learned what my good skills are and what I need to work on, like my communication. And I learned about my inner self, spirit, what I do for people." With regard to learning about helping, students' responses indicated that they became aware that helping benefits the helper, helping is a positive social force, and helping includes particular roles and behavior. Students also reported that they learned about specific issues or topics, such as other cultures, homelessness, and their communities, careers, and work-related skills. One student mentioned that she learned about "how to file, correct mistakes, organizational skills, work experience."

The most clear-cut findings in this section reveal that school auspices make a difference in what students perceive to have learned. While more than half of all of the students reported that they learned about helping others, the greatest proportion of religious school students note that they learned about helpingprobably as a reflection of their schools' philosophies of service and helping. Also, based on their students' observations, religious schools apparently place greater emphasis on the personal benefits of helping and the ethical nature of helping.

b. Future intentions. Analysis of the students' intentions to participate in community service in the future reflects a positive attitude toward service activities: Seventy-one percent of the students claimed they would continue to participate in community service experiences, in contrast to twenty percent who reported they will not continue and the remainder, who were undecided or unsure of their future activities. ${ }^{124}$ Students in the religious schools were most likely to plan on future volunteer activities, while those in public schools were most likely to rule out such activities. Students in schools that do not require service activities tended to plan on future service, while those in schools that require service tended to be undecided.

7. Summary of Student Perspectives. The students in high school community service programs have expressed their views through this project: While positive and serious about their experiences, they also expressed concerns about organizational problems, time management, and potential participation problems. While most students received supervision, only half report being trained, evaluated, or recognized for their work. They defined a quality service experience as one in which participants bring a positive and dedicated attitude to do serious hands-on service activities. Schools and families motivated these students to do service, yet their own attitudes and exposure to service role models, primarily outside their own families, greatly affected them, too. One-third of the students did not see the school as encouraging a connection between the service and their learning; those who did see a connection recognized it via activities or assignments at school. Of the

124. See Appendix Table 10. 
few students who recalled discussing their service experiences at school, most did so with teachers in a variety of settings.

Students most enjoyed service, learning, and social aspects of their experiences, while organizational conditions and time constraints presented barriers to fulfilling participation. They most feared making mistakes or being rejected by those they encountered in service, although training or participation apparently alleviated these fears. As a result of their high school community service experiences, students learned about themselves, helping, and problems in their community. Students became committed to doing service, particularly once they experienced it. However, they needed support to participate in organized programs and encouragement to connect service to their educational experiences.

\section{E. Summary}

Students in public and private high schools carry out numerous tasks as volunteers in their schools and communities. It appears that their schools contribute importantly toward socializing them into roles and attitudes commensurate with a service and helping ethic-one that is compatible with the demands of a democratic society where citizens depend upon one another for assistance. That said, our findings also reveal that the success of this process varies according to the program structure, the sponsorship, the mandate, and the social and cultural diversity of the schools. Successful collaboration between schools and community organizations may enhance the service activities for the students, because the program structures are more fully developed in these situations, and potential problems may be avoided or alleviated with clear communication.

IV

\section{CONCLUSIONS AND RECOMMENDATIONS}

\section{A. Competing Demands}

Many high schools do not adequately articulate their community service goals with their educational mission. This became apparent in our interviews with school personnel, as well as with students; one-third of the students claimed they received no encouragement from the school to integrate their service experience with their classroom learning. Numerous observers have noted the lack of clarity in program goals, ${ }^{125}$ the need for integration with the educational goals of the school, ${ }^{126}$ or a "a guiding interpretive framework." 127

125. See Ernest Boyer, Foreword, in Charles HARrison, STUDENT SERVICE: The New CARNEGIE UNIT (1987); Furco, supra note 24, at 396; Kraft, supra note 11, at 143; Youth Service California, supra note 21 .

126. See Mintz \& Liu, supra note 79, at 14 . 
This is problematic for the schools that do not consider their programs to be oriented toward service learning, as well as those that emphasize various facets of service learning. In the former, some programs appear to exist because someone in the school has identified service as a good idea without defining its goals; in the latter, some schools profess to be involved in service learning, but spend little effort or resources in providing students with the opportunity to reflect on service as a learning process.

With respect to the reputed goal of educating for citizenship, it is not clear how successful the schools are in socializing their students into roles of civic participation. An understanding of the community, its political processes, or how to meet its needs may receive less emphasis than personal growth and development in school community service programs. While this focus on personal development may be helpful for some students, it may deter them from focusing on the more collective aspects of civic participation. Wade has noted that the traditional stress placed by public schools and society on individual success has resulted in an emphasis on students feeling good about themselves for doing service, at the cost of not having meaningful ties to the community or being involved in the processes of democracy. ${ }^{128}$ Community service as a panacea for students' low self-esteem may represent a misplaced emphasis on the importance of self-esteem. ${ }^{129}$ The students' responses clearly indicate that they perceive little of their community service activities as being directly related to civic participation, politics, or community solidarity, as it is defined in the literature. The students overwhelmingly value the service and helping aspects of their community service experience, but rarely use terms that could be interpreted as citizenship, community action or change, or the public good.

While not as devoted to a social action program as some might prefer, ${ }^{130}$ the service and helping activities prevalent in service programs and valued by so many students can serve as a prelude to more active and informed civic participation. After all, de Tocqueville marveled at the way Americans helped out one another in their voluntary associations, and student service appears to have the potential of being part of that cultural phenomena. Also, given the cautiousness generally found in schools, especially public schools, they are not likely to sponsor students' participation in controversial issues. However, rather than simply discounting or eliminating community service activities, because they may be too charitable rather than political in orientation, schools need to sensitize students to avoid being paternalistic and to understand the socio-political implications of the server-served relationship. If, through service and helping, students learn about

127. Thomas Batchelder \& Susan Root, Effects of an Undergraduate Program to Integrate Academic Learning and Service: Cognitive, Prosocial Cognitive, and Identity Outcomes. 17 J. AdOLESCENCE 341, 353 (1994).

128. Wade, supra note 75, at 199.

129. For a critical review of self-esteem literature, see R.F. Baumeister, Should Schools Try to Boost Self-esteem?, 20 AM. EdUCATOR 14-19, 43 (1996).

130. See e.g., Boyte, supra note 35, at 766; Kahne \& Westheimer, supra note 39, at 597. 
these issues, their service at a later time in life may become more of a vehicle for social change-and less of a source only for self-satisfaction.

The more socially elite students and the students in religious schools are more likely to report a growing awareness of the plight of those less fortunate than themselves. However, this awareness does not necessarily translate into future action, since many students perceive this as "lucky" for themselves rather than necessitating continued action on their part to alleviate the situation. The religious school students, in particular, are the most likely to work toward social change, primarily due to religious ethics and their incorporation into their service activities. The nonsectarian and public schools have less success in creating future volunteers working for social change, due to their different educational goals and many other related factors, such as a lack of integration of service and learning in the curriculum and educational objectives.

The "original mission of public schooling ... was to create active and informed citizens," and community service is one of the avenues to fulfill that promise. $^{131}$ Ironically, to the extent community service serves as a means to socialize students for active citizenship, our observations lead us to speculate that the private schools work more diligently in preparing their students-frequently society's future elites - for the role of civic leadership. Furthermore, among public schools, suburban schools are more likely to achieve this mission than large inner-city schools.

Faced with crowded classrooms, substantial turnover of students, numerous nonEnglish-speaking students, working parents either too busy or ill-prepared to make demands regarding their childrens' education, alienated youth who express little hope in furthering their education yet alone volunteering, inner city public schools lack many of the common supports for community service found in public schools serving middle class areas. ${ }^{132}$

\section{B. Clarity of Program Elements}

1. Communication and Collaboration with Community Organizations. Greater efforts need to be devoted to creating the sustaining linkages between schools and local organizations where the students' service occurs. This could be achieved through greater and improved communication between the two groups, especially about their respective goals relevant to community service. Annual school-sponsored orientations to community service, the appointment by the school of a liaison to the local groups, and a program to familiarize students and/or school personnel of community needs by representatives of the local groups are ways to strengthen the linkages between the two groups.

For example, in Southern California a coalition of personnel within private schools has regular meetings in which they discuss programmatic issues, invite staff from community organizations, initiate efforts to further understand the

131. RAHIma C. WADE, COMmUnity SERVICE LEARNING A GuIDE TO INCLUDING SERVICE IN THE PUBLIC SCHOOL CURRICULUM 1-4 (1997).

132. Raskoff \& Sundeen, supra note 108 , at 85. 
sentiments of program participants, and enjoy a buffet luncheon. While these meetings serve important recruiting and communication functions, the rooms in which these meetings take place are a barrier to admitting other participants. The intimate nature of and personal relationships fostered by these gatherings would be hindered by larger attendance.

2. Important Resources: Time and Money. At a workshop the authors held to discuss the study findings with representatives from the schools and community organizations, those from public schools clamored for more participation in such networking opportunities. The private school personnel were more able to continue their networking activities with facilities and resources, while the public school personnel seemed overwhelmed with regulations and lack of resources.

Schools able to define their need for resources to support community service programs often succeed in gathering such resources from existing situations (such as gradually redefining a teaching position into a volunteer coordinator position) or from new sources (for example, enabling a parent-volunteer to coordinate and gain funding for program activities, eventually creating a paid position). Most of these are nonsectarian schools with flexible budgets or suburban public schools with supportive administrators. Most public schools, particularly those in the urban centers, may be overwhelmed with their typical responsibilities and define service as an extra activity that adds to, rather than enhances, their educational tasks.

\section{The Need for Organization}

High school students are very clear about their opinions of high school community service programs. Their perceptions that these programs need to be organized to accommodate time constraints and prepare students for volunteering with adequate training reflect the concerns of school personnel and the staff in community organizations. Students recognize the support and encouragement their high schools are able to give them and appreciate direct service activities in which they can see clients and the results their efforts gain.

The case study illustrates how students gain a tremendous amount of selfawareness and an increasing awareness of service through their activities. While this awareness of how helping their community benefits them and others is a positive change, this cannot necessarily be equated with the development of civic engagement. Most students in this age group focus on their own experiences; developing an awareness of their place in the world and the responsibilities of living in a democracy presents a formidable challenge. However, perhaps the growing awareness of the possibilities of service that is generated by community service activities plants the seeds of future civic engagement.

The impact of school-mandated service for this population is relevant in encouraging this process, because some students experience it as simply one other item to check off the list for graduation and then never be bothered with again. 
This signifies the importance of having a clear rationale for service and integrating it into the educational objectives of the school, especially in schools that mandate service. This gives some context and relevance to the requirement, rather than separating it from the rest of the work done at school.

As reported in the case study and literature, the existence of a mandate for service has an impact on future volunteering behavior. Students required to do service are less likely than other volunteers to plan on volunteering in the future. This case study highlights differences among students in different types of schools: Public school students are less likely than students in private schools to indicate they will volunteer in the future. However, nonsectarian students in schools requiring service are the least likely to indicate they will volunteer in the future and are the most undecided as to their future volunteer plans. Thus, the schools' auspices are as important as the mandate for supporting the development of future volunteers.

\section{Challenges}

The effective implementation of program goals requires greater effort in defining the goals of service vis à vis the school's educational goals; improved coordination with community organizations; heightened attempts to encourage students to reflect on their experiences and integrate them with the school's educational mission; increased training opportunities for teachers regarding methods of reflection and integration; and greater attention to training, recognition, and program evaluation.

This review of the literature and report of a county-wide study in Los Angeles illustrates the need for more research on high school community service. A longitudinal study that includes comparison of various types of community service programs (length of time, type of activity, rationales, mandates, etc.) would help predict the long-term impact of different service programs. Studying a group of students who do not participate in any service would also be useful, to distinguish why they do not participate and how their long-term civic behaviors differ from volunteering youth.

It is clear that high schools are important institutions in promoting and socializing youth into volunteer behaviors, along with families and religious organizations. However, high school community service programs and activities are not easily developed nor supported, particularly considering school auspices and resources. 


\section{APPENDIX: TABLES 1-10}

The results from significance tests (Chi Square) are indicated by asterisks: * for $\mathrm{p}<.10$ and $* *$ for $\mathrm{p}<.05$. Thus row headings with asterisks indicate that the figures in each sub-category (nonsectarian, religious, and public) in that table are significantly different from each other so as not to be a random occurrence.

TABLE 1

High SCHOOL COMMUNITY SERVICE PROGRAMS: BASIC DESCRIPTIONS

\begin{tabular}{lcccc}
\hline & Total & Nonsectarian & Religious & Public \\
\hline Community service program or activities & $81.9 \%$ & $76.9 \%$ & $86.6 \%$ & $80.9 \%$ \\
Students doing service (averaged \#) & 339 & 220 & 317 & 373 \\
School Size (\# students)** & 1170 & 236 & 470 & 1654 \\
Students doing service (ratio of population)*** & .49 & .80 & .73 & .31 \\
Mandate:** & & & 72.0 & 37.0 \\
$\quad$ Require Service for Graduation & 51.2 & 65.0 & 18.0 & 48.9 \\
$\quad$ Optional Credit for Service & 34.6 & 10.0 & 10.0 & 14.1 \\
\hline No Credit for Service at all & 14.2 & 25.0 & & \\
\hline
\end{tabular}

Source: Mailed survey returned by 385 high schools, including 82 nonsectarian schools, 34 religious schools, and 269 public schools.

Tables 2-10 present data analysis from 281 student interviews, including from 45 students attending nonsectarian schools, 94 in religious schools, and 142 in public schools (77 suburban, 65 central city). The primary questions that elicited the following responses are listed in the first cell of each table. However, due to the qualitative style of the student interviews, answers may have also emerged in response to other questions. In such cases, student responses that correspond to the question at hand were coded appropriately. 
TABLE 2

STUDENT DESCRIPTIONS OF THEIR HIGH SCHOOL COMMUNITY SERVICE ACTIVITIES

\begin{tabular}{lcccc}
\hline $\begin{array}{l}\text { Question: "We'd like to know about your } \\
\text { volunteering and community service that you }\end{array}$ & & & & \\
have done through the school. Tell me about & & & & \\
your most recent volunteer experience." & Total & Non-sectarian & Religious & Public \\
\hline Community service experience** & $81.5 \%$ & $93.3 \%$ & $86.2 \%$ & $74.6 \%$ \\
No community service experience & 18.5 & 6.7 & 13.8 & 25.4 \\
Activities:** & & & & \\
At own school & 19.9 & 14.0 & 15.6 & 24.6 \\
At another school & 24.8 & 20.9 & 27.3 & 24.6 \\
At a nonprofit organization & 35.4 & 37.2 & 46.8 & 27.8 \\
Other location & 19.9 & 27.9 & 10.3 & 23.0 \\
Type of service:** & & & & \\
Direct & 34.7 & 62.8 & 28.6 & 28.8 \\
Leadership & 2.9 & 7.0 & 1.3 & 2.4 \\
Fund raising & 8.2 & 7.0 & 1.3 & 12.8 \\
Indirect & 34.3 & 20.9 & 44.2 & 32.8 \\
Maintenance & 8.6 & 2.3 & 5.2 & 12.8 \\
Other & 11.5 & 0.0 & 19.5 & 10.4 \\
\hline
\end{tabular}


TABLE 3

SOURCES OF ENCOURAGEMENT FOR DOING SERVICE

\begin{tabular}{lcccc}
\hline $\begin{array}{l}\text { Question: "Do you feel encouraged to do com- } \\
\text { munity service by anyone in particular?" }\end{array}$ & Total & Non-sectarian & Religious & Public \\
\hline Who encourages service: High School** & 30.6 & 38.6 & 44.7 & 18.6 \\
$\quad$ For Required Schools: High School encourages** & 34.4 & 40.0 & 47.4 & 17.5 \\
$\quad$ For Not-Required Schools: High School encourages & 26.0 & 38.2 & 31.3 & 19.5 \\
Who encourages service: No one & 23.7 & 31.8 & 19.1 & 24.3 \\
$\quad$ For Required Schools: No one encourages & 21.9 & 50.0 & 20.5 & 19.0 \\
$\quad$ For Not-Required Schools: No one encourages & 26.0 & 26.5 & 12.5 & 28.6 \\
Who encourages service: Family & 21.6 & 22.7 & 23.4 & 20.0 \\
\hline
\end{tabular}

Note: Multiple answers are possible; thus, each row indicates part of a $2 \times 4$ table whereby the residual (no answer) category for each cell consists of the difference between 100 and the figure noted here.

TABLE 4

SERVICE LEARNING SUPPORT: ENCOURAGING THE CONNECTION BETWEEN SERVICE AND LEARNING

Question: "Do you feel encouraged by the school to think about the relationship between your community service and what you are learning in your classes?"

Total Non-sectarian Religious Public

Encouragement to link service with learning**

Yes, I feel encouraged to link service with learning**

54.8

40.5

84.9

40.7

No, I do not feel encouraged to link service with

45.2

59.5

15.1

59.3 learning 
TABLE 5

ORGANIZATIONAL ELEMENTS

Questions: "Did you have a supervisor while volunteering?" "Were you trained to do this job?" "Did you receive any recognition or awards for your work?" "Was your work evaluated in some way?"

Total Non-sectarian Religious Public

Supervision:

Yes, supervised

No, no supervision

Training:

Yes, trained

No, no training

Recognition:**

Yes, recognized

No, no recognition

\section{Evaluation:}

86.4

13.6

40.7

59.3

36.4

63.6

92.7

87.9

83.2

7.3

12.1

16.8

13.6

0.7

39.0

36.8

43.8

.3

61.0

63.2

56.3

6.4

25.0

25.0

75.0

75.0

53.1

Yes, evaluated

44.1

41.5

50.0

41.6

No, no evaluation

55.9

58.5

50.0

58.4

TABLE 6

POSITIVE EXPERIENCES: WHAT STUDENTS LIKED MOST ABOUT THEIR COMMUNITY SERVICE

\begin{tabular}{lcccc}
$\begin{array}{l}\text { Question: "What did you like most about } \\
\text { your community service experience?" }\end{array}$ & Total & Non-sectarian & Religious & Public \\
\hline Service Orientation** & 47.8 & 61.4 & 53.2 & 40.0 \\
Social Aspects & 36.0 & 34.1 & 36.2 & 36.4 \\
Learning & 19.4 & 25.0 & 12.8 & 22.1 \\
\hline
\end{tabular}

Note: Multiple answers are possible; thus, each row indicates part of a $2 \mathrm{x} 4$ table whereby the residual (no answer) category for each cell consists of the difference between 100 and the figure noted here. 
TABLE 7

NEGATIVE EXPERIENCES: WHAT STUDENTS LIKED LEAST ABOUT THEIR COMMUNITY SERVICE

Question: "What did you like least about your community service experience?"

\begin{tabular}{lcccc} 
your community service experience?" & Total & Non-sectarian & Religious & Public \\
\hline Nothing (I liked everything)* & 21.9 & 9.1 & 21.3 & 26.4 \\
Site \& Program Conditions & 23.7 & 20.5 & 24.4 & 24.2 \\
Time Constraints* & 15.5 & 22.7 & 19.1 & 10.7 \\
Personal Issues & 14.0 & 18.2 & 11.7 & 14.3 \\
Inefficacy* & 11.5 & 20.5 & 7.4 & 11.4 \\
Annoying People & 10.1 & 15.9 & 6.4 & 10.7 \\
Seeing Suffering People* & 6.5 & 13.6 & 7.4 & 3.6 \\
\hline
\end{tabular}

Note: Multiple answers are possible; thus, each row indicates part of a $2 \times 4$ table whereby the residual (no answer) category for each cell consists of the difference between 100 and the figure noted here.

TABLE 8

STUDENTS' FEARS AND CONCERNS

\begin{tabular}{lcccc}
\hline $\begin{array}{l}\text { Question: "Did you have any fears or con- } \\
\text { cerns about doing community service?" }\end{array}$ & Total & Non-sectarian & Religious & Public \\
\hline None, no fears or concerns & 46.8 & 47.7 & 45.7 & 47.1 \\
Yes, I had fears and/or concerns & 53.2 & 52.3 & 54.3 & 52.9 \\
Making Mistakes** & 12.6 & 36.4 & 4.3 & 10.7 \\
Rejection* & 7.9 & 4.5 & 12.8 & 5.7 \\
\hline
\end{tabular}

Note: Multiple answers are possible; thus, each row for "Mistakes" and "Rejection" indicates part of a $2 \times 4$ table whereby the residual (no answer) category for each cell consists of the difference between 100 and the figure noted here. 
TABLE 9

THE IMPACT OF COMMUNITY SERVICE: WHAT STUDENTS LEARNED

Question: "What do you feel you learned from your community service experience?" "Has your community service experience made you more aware of anything?"

Total Non-sectarian Religious Public

\begin{tabular}{lrrrr}
\hline (I learned about) Myself & 54.7 & 59.1 & 54.3 & 53.6 \\
Helping** & 54.0 & 47.7 & 64.9 & 48.6 \\
$\quad$ Helping helps me & 24.5 & 20.5 & 26.6 & 24.3 \\
$\quad$ Helping as a positive force** & 24.1 & 22.7 & 40.4 & 13.6 \\
$\quad$ Helping Roles & 16.2 & 9.1 & 2.8 & 20.7 \\
Issues & 25.5 & 43.2 & 18.1 & 25.0 \\
\hline
\end{tabular}

Note: Multiple answers are possible; thus, each row indicates part of a $2 \times 4$ table whereby the residual (no answer) category for each cell consists of the difference between 100 and the figure noted here.

TABLE 10

\section{FUTURE VOLUNTEERING INTENTIONS}

Question: "Do you think you might do something different in the future as a result of your community service experience?" "Do you think you will do community service activities or volunteering in the future?"

Total Non-sectarian Religious Public

Future Volunteering:*

Yes
No
Maybe

71.0

19.9

9.1

68.3

18.2

13.2

Maybe

For Not-Required Schools:

$$
\text { Yes }
$$

No

Maybe
73.6

21.8

4.5
76.7

16.3

7.0

44.4

79.3

61.1

22.2

10.3

25.9

33.3

10.3

13.0

\begin{tabular}{lrrrr} 
Yes & 73.6 & 85.3 & 84.6 & 65.1 \\
No & 21.8 & 14.7 & 15.4 & 27.0 \\
Maybe & 4.5 & - & - & 7.9 \\
\hline
\end{tabular}

